\title{
Improving Cognitive Development of Students by Reading Corner Program in Elementary School level
}

\author{
Maratul Qiftiyah \\ Postgraduate Programs, PGMI, Universitas Islam Negeri (UIN) Sunan \\ Kalijaga Yogyakarta, Indonesia \\ Email:maratulqiftiyah@gmail.com
}

\begin{abstract}
Cognitive development is one of the most important children's development experiences. In essence, this potential is determined at the time of conception which is influenced by hereditary factors, but this cognitive potential can also develop depending on environmental factors and the maturity of the opportunity given to determine the maximum developmental limits at the level of intelligence. Reading is one of the most important parts of every type of learning process. Through reading, activities would get a lot of knowledge that can lead to success. This research aims to describe the cognitive development of students through reading corners. This type of research is field research, using a qualitative approach to the descriptive method. The research was carried out at SDN 02 Nusa Bakti, South Sumatra province, Indonesia. The research subjects are teachers and students. The data were obtained from interviews and observations. The results showed that a fun reading corner activity as an effort to implement literacy reading movements could develop cognitive abilities of students, including students doing assimilation, and accommodation processes to achieve equilibration, and students are more enthusiastic and motivated to increase their reading interest.
\end{abstract}

Keywords: Cognitive Development, Reading Corner, literacy, elementary school

\section{INTRODUCTION}

In the 4.0 era of education 4.0, students' interest in reading especially at the elementary school level needs to be improved (Handayani et al., 2018). 


\section{Mudarrisa: Jurnal Kajian Pendidikan Islam, Vol. 12, No. 1, 2020}

The era of education 4.0 is a separate challenge, not only for elementary schools in fortifying students from the negative effects of the rapid use of technology, especially in the daily lives of students. The era of education 4.0 is a modern era in which there are digital systems in almost every aspect of life, including aspects of education. With the rapid development of technology, this program will be a direct or indirect challenge for students.

Education 4.0 is not only based on the use of technology, but students' interest in reading also needs to be improved to welcome education 4.0. The rapid flow of information and technology in the era of education 4.0 has an impact on the limited time students have to read. The reading and writing ability of students are very important for students to be able to follow all developments, especially related to their world of education. (Yuriza, et al., 2018; Juhanda \& Maryanto, 2018).

At this time, students are faced with the problem of how to overcome time constraints and can read at a relatively short time but can get as much information as possible (Rahmania et al., 2015). There is a statement about how to do reading activities effectively without wasting time or bored, that needs to be answered. In line with this statement, it appears that reading skills are needed by students along with the rapid development of information and technology at this time. Hanggi (2016) stated that reading literacy can be a tool for students to recognize, understand, and apply the knowledge gained at school. Basic literacy, including reading literature, must be instilled since basic education 
(Ristanto et al., 2017). So, the students can add their abilities to access information or knowledge. Literacy will direct students to understand a message (Hernowo, 2003).

The importance of literacy was also conveyed by the Ministry of Education and Culture (2016) that the culture of literacy inherent in students will affect the level of success and ability of students to understand information analytically, critically, and reflectively. Cultural literacy supported student's activity by increasing their knowledge well. The government has also issued a School Literacy Movement or Gerakan Literasi Sekolah (GLS) program that aims to foster children's character through a literacy culture include reading and writing (Latifa, 2017; Triyanti \& Hidayah, 2018). A suitable way to foster a culture of literacy in reading and writing can be done during the elementary school period.

The elementary school level is an important period in the growth and cognitive development of students (Vandenbroucke et al., 2018). It was a suitable time to instill good habits for the students. If embedded from an early age, then this habit would be able to become good habits inherent in children and will continue to stick to adulthood. Reading habits can be started early to get used to it. Reading is the basic key to student's success in a variety of subjects. Reading habits can open a window of insight that will convey to get the things needed during school for the students. Reading is also an ability that must be possessed by every student. This of course can be familiarized through reading corner activities. 
The existence of the reading corner activity aims to practice children's habits in applying literacy to reading and writing. It will certainly be very useful for the future because reading and writing will add insight to students. Reading and writing activities will also affect cognitive development. So, this research has conducted a study on the Cognitive Development of Students through Reading Corner at the elementary level.

\section{METHODS}

The research used qualitative field research methods by descriptive approach. This research was conducted at SDN 02 Nusa Bakti, Belitang III District, east Ogan Komering Ulu (OKU) Region in south Sumatra Province, Indonesia. The main objects in this study were class $\mathrm{V}$ with the teachers are Mrs. Nurul Isnaini Fadhillah, and class V students totaling 28 peoples.

The data were obtained by interview and observation techniques. Data analysis techniques used are data reduction, data presentation, and drawing concluding. The focus of this research was to describe the cognitive development of students through reading corner activities.

\section{DISCUSSION}

Based on observations and interviews with teachers at SDN 02 Nusa Bakti, it was obtained information that the school had made several reading corner programs and made creative school environments with text. The literacy corner was named the reading corner. Reading corner is one of 
the programs initiated by elementary schools to increase students' interest in reading. The corners in every corner of the class with a collection of storybooks and supporting textbooks (Wulanjani \& Anggraeni, 2019). The reading corner in at SDN 02 Nusa Bakti, South Sumatra, Indonesia was showed in Figure 1.

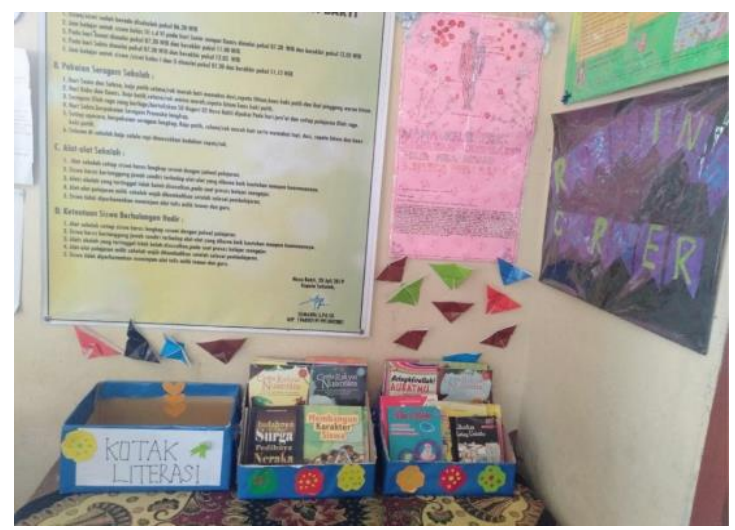

Figure 1. Reading Corner of Class V at SDN 02 Nusa Bakti, South Sumatra

Reading is a process that involves physical and mental activity. One physical activity in reading is when the reader moves his eyes along the lines of writing in the reading text. Reading involves mental activities that can ensure maximum understanding. The reading activity did not only move the eyeball from the left to right margins but is far from it, namely the activity of thinking to understand writing for the sake of writing. By reading, the students more activate their brain to work by understanding what they read. Knowledge formed from there supports their experience. 
Reading is the student's basic skills, they have to know about how to read properly. The students have to reach their goal in school, so their behavior has to be developed seems like reading, thoughts, cognitive developments, emotional, and student-teacher relationships (Zee \& Bree, 2016). The students to be more active in the reading corner in SDN 02 Nusa Bakti, South Sumatra, and not only reading but also other activities that showed in Figure 2.

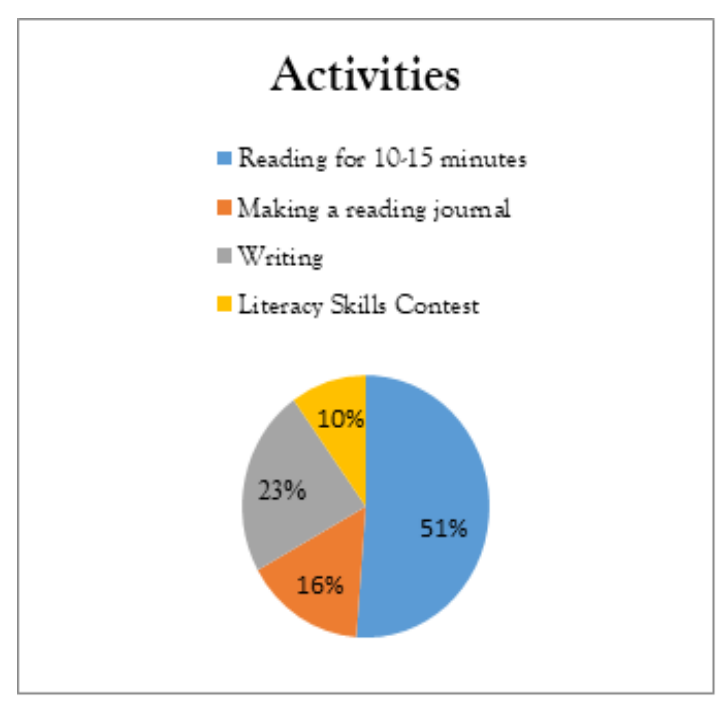

Figure 2. Graph of Reading Corner activities at SDN 02 Nusa Bakti, South Sumatera

Some activities that support reading corners in schools include: First, do reading activities at least 10-15 minutes before they started classroom learning. This activity has been carried out at $51.0 \%$ and the less was Literacy Skills Contest.

The reading activity is carried out by teachers and students. The textbooks used in this activity include a storybook that adapts to the 
characteristics and desires of students. Teachers at SDN 02 Nusa Bakti, South Sumatra, stated that this activity was carried out in two ways, including at Monday, he gave an example to students about how to read fairy tales. Then, from Tuesday to Saturday, each student is given the task to read a fairy tale in front of his classmates and also followed by clear intonation and body movements. The student's activity in the reading corner as shown in Figure 3. The students interested to open the book and read it before entered the class.

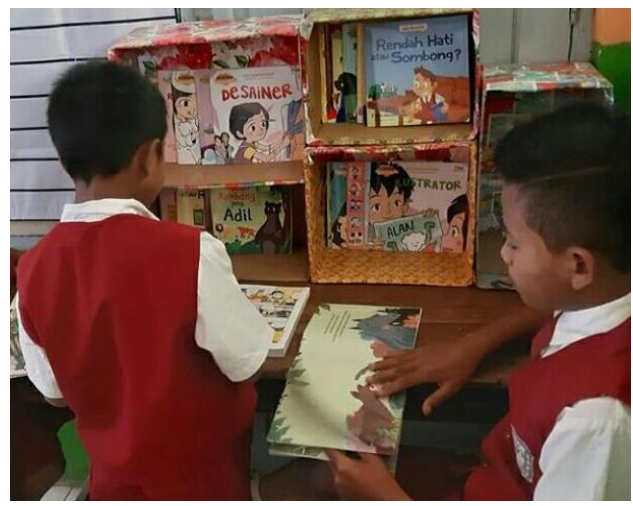

Figure 3. Students reading activity before classroom learning

Literacy cannot be separated from the world of education. In the beginning, literacy was known as reading skills, but over time literacy gained significant meaning. This is in line with the opinion which states that literacy is a capability that is very important in dealing with everyday problems. Characteristics of an individual who has good literacy skills include being able to understand and read graphs, tables, diagrams, able to interpret mathematical abilities in everyday life in various contexts (Harjo et al., 2019; Pamungkas, 2017). Sometimes, students interested to read 


\section{Mudarrisa: Jurnal Kajian Pendidikan Islam, Vol. 12, No. 1, 2020}

the book with some visualization or colorful texting. Reading is a kind of cultural literacy and nowadays, the development of reading skills described the student's curiosity then they will learn what their subject.

Cultural literacy needs to be developed in elementary schools so that students can learn to find information related to learning which is certainly beneficial for them (Heitmann et al., 2017). More students understand the importance of literacy, the more opportunities for students to compete in modern times. Although the government has implemented the GLS program, teachers must be creative in designing class literacy programs especially reading, to create conducive and pleasant classroom conditions (Akbar, 2017).

Besides, having mathematical literacy skills is also required to have literacy skills in reading and writing. It was important because in daily life always requires speaking activities, both within the family and in the school environment. The statement is in line with the opinion which states that speaking is an ongoing and continuous process since elementary school students have learned the process of speaking, that is, children learn how to talk about using good and appropriate language formally speaking in public through speech, or simulating through conversation text. In the $4^{\text {th }}$ through $6^{\text {th }}$-grade aspects of children's speech are much higher, such as children learning to speak in public formally through speeches, or simulations through text conversations (Yuliana et al., 2015). This is in line with the opinion of Heriawan and Pribadi in their research stating that reading and writing are ways to find direction and meaning, 
beauty, and meaning in life that can create and build the lives of students (Heriawan \& Pribadi, 2018).

Yulia (2015) stated about foster children's reading habits we have laid the foundation to help children become lifelong learners or lifelong learners because books are a window to the world that will take us and children our children wherever we like. Other forms that are carried out by educators in the reading activity at least 15 minutes before the start of learning are reading silently individually, reading together with sound, and reading with the mentor's guidance. According to Antoro, the form of fairy tale reading activities before lessons can be carried out by adding music to improve students' reading (Antoro, 2017).

Second, discuss student progress by keeping a reading journal. On this occasion, teachers motivated the students, so that reading activities are used as their habits, both within the scope of the school and at home. Themes that have been read by students should be written in a journal so that educators know what students have read. This activity has only been carried out by percentage of $16.0 \%$ because students have not fully carried out this activity, the obstacle is that students are not painstaking in writing what they have read.

Third, promote writing activities. The written form used for students can be in the form of short stories, poetry, and opinions. Most have not been arranged properly, this is necessary to improve students' writing and reading skills. Students wanted their writing activity to get a good level, so students would read their writing many times before 


\section{Mudarrisa: Jurnal Kajian Pendidikan Islam, Vol. 12, No. 1, 2020}

submitting it to educators. This activity has been carried out at a percentage of $23.0 \%$ because this activity is related to Indonesian language subjects, so students are competing to get a good level.

Fourth, students' literacy skills contests. The kinds of literacy skills that are competed at school include speech contests, poetry reading contests, and poster making contests. These activities are generally carried out after the final semester exams. This activity has only been carried out a percentage of $10.0 \%$ because the reading corner activity at this school has not been implemented long ago. Therefore, a literacy skills contest is held so that students are more enthusiastic to do this activity.

Wulandari stated that competition and appreciation activities can stimulate students' enthusiasm in reading and writing activities (Wulandari, 2017). Therefore, teachers can motivate students by giving appreciation to students who can encourage themselves to display reading skills. For example, favorite readers for this month, the best short story writers, the best storytellers, the best poet writers, and the selection of library ambassadors.

According to Piaget (in Arimbi, et al, 2018), if students aged 3-12 years old are given different objects and asked to make the same classification into one, several possibilities occur. Students arranged objects not only based on similarity but also adjust spaces, lines, shapes, colors, etc. so that they form more images. The older student classifies objects structurally, in other words, and other objects systematically. 
Therefore, student's cognitive development needs to be stimulated or given a stimulus to increase, especially the classification characteristics at the stage of cognitive development with the holding of reading corner activities at school. Modern experts argue that reading is an absolute skill that must be possessed by them from an early age. By reading, the students can take lessons in school, and also open a window of knowledge and a world that is stock for the success of his success (Wang, 2016).

An aspect that is very important to know and understand from basic childhood development is the cognitive aspect. Cognitive development is a very comprehensive development related to the ability to think, such as the ability to reason, remember, memorize, solve real problems, idealize, and creativity. Cognitive development can affect a student's mental and emotional development and language skills. Student's attitudes and actions are also related to thinking abilities. Thus, cognitive development can be said to be the key to non-physical developments (Bujuri, 2018).

Jean Piaget stated that the child is born with several concepts, which can give consent to the child's initial interaction with the environment. The sensorimotor scheme determines the child's early experience. On the other hand, only events that can be assimilated into the scheme can be responded to by the students, if the event can occur it will determine the limits of experience in children. Except through experience, this initial scheme is expected. Each experience has a unique 


\section{Mudarrisa: Jurnal Kajian Pendidikan Islam, Vol. 12, No. 1, 2020}

element that must be possessed by the stages of the child's cognitive development.

Interaction with the environment, student's cognitive development stages can change and can allow the development of sustainable experiences. But Piaget said that this was a slow process because new schemes would always develop from existing schemes. For this method, the development of children's intelligence that starts with a spontaneous reaction in their environment will always increase to a level that can increase the potential where the child can develop a mental state that utilizes these results (Ibda, 2015).

The existence of students' reading corner activities at SDN 02 Nusa Bakti, South Sumatera province, Indonesia could adjust themselves to the environment so there is the process of assimilation and accommodation. The students can read and add new knowledge and experience. Students can also adjust themselves to their environment, namely the movement of literacy reading through the reading corner of students can read activities for 15 minutes before they start learning. With the process of assimilation and accommodation, students can reach the equilibration process. Where students can balance between cognitive structures with their experiences in the school environment and home environment.

The existence of literacy movements in schools such as reading corner activities is a positive thing that can instill a culture of literacy at this time and can also improve the cognitive development of students following the stages proposed by Jean Piaget. 


\section{CONCLUSION}

Based on the analysis, the Reading corner program in GLS increased the student's reading interest that supports literacy reading movements. Reading corner activities also enhance cognitive development in students. With this activity students and educators will get many benefits to support teaching and learning activities. Therefore, it can be suggested that teachers must further develop creativity, meaning teachers must always be creative in various ways of providing activities so that students do not get bored doing it. Also, every teacher is encouraged to be able to integrate teaching materials with reading corner activities so that learning objectives and activities can be achieved.

\section{REFERENCES}

Akbar, Aulia. (2017). Membudayakan Literasi dengan Program 6M di Sekolah Dasar, JPsd (Jurnal Pendidikan Sekolah Dasar), 3 (1), 51.

Antoro, Billy. (2017). Gerakan Literasi Sekolah dari Pucuk Hingga Akar (Sebuah Refleksi). Banjarmasin: Direktorat Jenderal Pendidikan Dasar dan Menengah Kementerian Pendidikan dan Kebudayaan.

Arimbi, Yurike Dwi, Sri Saparahayuningsih, Mona Ardina. (2018). Meningkatkan Perkembangan Kognitif Melalui Kegiatan Mind Mapping. Jurnal Ilmiah Potensia, 3 (1), 65.

Budi Harjo, Badrun Kartowagiran, A. M. (2019). International Journal of Instruction. International Journal of Instruction, 12(4), 149-166.

Bujuri, Dian Andesta. (2018). Analisis Perkembangan Kognitif Anak Usia Dasar dan Implikasinya dalam Kegiatan Belajar Mengajar. Literasi: IX (1), 38.

Handayani, Adisyahputra, A., dan Indrayanti, R. (2018). Cor-relation Between Integrated Science Process Skills, and Ability to Read 
Comprehension to Scientific Literacy in Biology Teachers Students.

Biosphere: Jurnal Pendidikan Biologi, 11(1), 22-32.

Hanggi, Olovia Herlina. (2016). "Tiga Perubahan Kecil dalam Literasi Sekolah." Membumikan Gerakan Literasi di Sekolah. Yogyakarta: Lembaga Ladang Kata.

Heitmann, P., Hecht, M., Scherer, R., \& Schwanewedel, J. (2017). Learning Science Is About Facts and Language Learning Is About Being Discursive- An Empirical Investigation of Students ' Disciplinary Beliefs in the Context of Argumentation. Frontiers in Psychology, 8(June), 1-24.

Heriawan, Adang, Reksa Adya Pribadi. (2018). Bahasa Kita dan Pendidikan Kita. JPsd (Jurnal Pendidikan Sekolah Dasar), 4 (2), 155.

Hernowo, ed. (2003). Quantum Reading: Cara Cepat dan Bermanfaat untuk Merangsang Munculnya Potensi Membaca. Bandung: Mizan Learning Center.

Ibda, Fatimah. (2015). Perkembangan Kognitif: Teori Jean Piaget. Intelektualita, Volume 3, No-mor 1, Januari-Juni, 27-38.

Juhanda and Maryanto, Y. (2018). The Emergence of Biological Problems in Electronic School Books (BSE) Class X Reviewed from The Scientific Knowledge Domain of Scientific Literacy. Biosfer: Jurnal Pendidikan Biologi, 11(2), 121-125.

Latifa, U. (2017). Aspek Perkembangan pada Anak Sekolah Dasar: Masalah dan Perkembangannya. Jounal of Multidisciplinary Studies, $1(2), 185-196$.

Mualimah, Eka Nurul, and Usmaedi. (2018). Pengaruh Kebiasaan Membaca Terhadap Prestasi Belajar Bahasa Indonesia Peserta Didik Kelas V SDN Kubanglaban. Jurnal Pendidikan Sekolah Dasar, 4 (1), 46.

Pamungkas, Aan Subhan. (2017). Pengembangan Bahan Ajar Berbasis Literasi pada Materi Bilangan bagi Mahapeserta didik Calon Guru SD. JPsd (Jurnal Pendidikan Sekolah Dasar), 3 (2), 229.

Rahmania, Miarsyah, dan Sartono. (2015). The Difference Scientific Literacy Ability of Student Having Field Independent and Field Dependent Cognitive Style. Biosphere: Jurnal Pendidikan Biologi, 8(2), 27-34. 
Ristanto, Zubaidah, Amin, dan Rocman. (2017). Scientific Literacy of Students Learned Through Guided Inquiry. International Journal of Research and Review, 4 (5), 23-30.

Suyono, Harsiati, dan Wulandari. (2017). Implementasi Gerakan Literasi Sekolah pada Pembelajaran Tematik di Sekolah Dasar. Sekolah Dasar: Kajian Teori dan Praktik Pendidikan, 26 (2), 116-123.

Triyanti, H., \& Hidayah, N. (2018). Implementasi Program Gerakan Literasi Sekolah (GLS) ditinjau dari Tahap Pengembangan di SD Unggulan Aisyah Bantul. Fundamental Pendidikan Dasar, 1(1), 35-39. Vandenbroucke, L., Spilt, J., Verschueren, K., Piccinin, C., \& Baeyens, D. (2018). The Classroom as a Developmental Context for Cognitive Development: A Meta-Analysis on the Importance of TeacherStudent Interactions for Children's Executive Functions, 88(1), 125-164. https://doi.org/10.3102/0034654317743200.

Wang, A. (2016). Exploring the impact of teacher experience on questioning techniques in a Knowledge Building classroom. Journal of Computers in Education, 4(1), 27-42. https://doi.org/10.1007/s40692-016-0057-2.

Yuliana Rina, Isah Cahyani, dan Andoyo Sastromiharjo. (2015). Penerapan Strategi Partisipatif Melalui Media Gambar Denah dan Kartu Pancing Foto dalam Pembelajaran Pemahaman Konsep dan Berbicara Peserta didik Sekolah Dasar (Pra-Eksperimen pada Kelas IV SDN Layungsari 1 Kota Bogor). JPsd (Jurnal Pendidikan Sekolah Dasar), 1 (2), 3.

Yuriza, Adisyahputra, A, dan Sigit. (2018). Correlation Between Higher Order Thinking Skills and Level of Intelligence with Scientific Literacy on Junior High School Students. Biosfer: Jurnal Pendidikan Biologi, 11(1), $13-21$.

Zee, M., \& Bree, E. De. (2016). Students' self-regulation and achievement in basic reading and math skills: the role of student-teacher relationships in middle childhood. European Journal of Developmental Psychology, 5629(June), $1-16$. https://doi.org/10.1080/17405629.2016.1196587. 